\title{
PENGARUH METODE PRESENTASI DISKUSI DENGAN MEDIA POWERPOINT TERHADAP HASIL BELAJAR MATA KULIAH TEORI AKUNTANSI PADA MAHASISWA PROGRAM STUDI PENDIDIKAN EKONOMI AKUNTANSI DI FKIP UNIVERSITAS ISLAM RIAU
}

\author{
Purba Andy Wijaya \\ Prodi Pendidikan Ekonomi Akuntansi, Fakultas Keguruan dan Ilmu Pendidikan \\ Universitas Islam Riau \\ Riau, Indonesia \\ e-mail : purbaandywijaya@yahoo.co.id
}

\begin{abstract}
Abstrak
Penelitian ini bertujuan untuk mengetahui pengaruh metode presentasi diskusi yang menggunakan media powerpoint terhadap hasil belajar, Rancangan penelitian ini menggunakan desain kuasi eksperimen, kelas kontrol melaksanakan metode presentasi dengan menggunakan media makalah dan kelas eksperimen melaksanakan metode presentasi diskusi dengan menggunakan media powerpoint. Kelas penelitian tidak menggunakan kelas yang suda ada, melainkan dibentuk kelas sendiri. Masing-masing kelas penelitian berjumlah 40 mahasiswa. Teknik analisis data menggunakan uji T. Dari hasil uji hipotesis yang dilakukan, diperoleh hasil penelitian yang menunjukkan bahwa terdapat pengaruh metode presentasi diskusi yang menggunakan media powerpoint terhadap hasil belajar mata kuliah Teori Akuntansi.
\end{abstract}

Kata kunci : metode presentasi diskusi, media powerpoint, hasil belajar teori akuntansi

\begin{abstract}
The objective of this research to determine the effect of presentation method that uses media powerpoint discussion on learning outcomes, study design using quasi-experimental design, implement control class presentation methods using paper medium and experimental classes implement the method of discussion presentation using powerpoint media. Class research suda not use existing classes, but the class itself was formed. Each class numbered 40 students study. Analysis using $T$ test result of hypothesis testing is done, the results of studies showing that there are significant discussion method that uses a media presentation powerpoint on learning outcomes of Accounting Theory courses

Keywords : presentation method of discussion, media powerpoint, learning outcomes of accounting theory
\end{abstract}

\section{PENDAHULUAN}

Banyak model pembelajaran yang dapat digunakan sebagai alternatif dalam kegiatan pembelajaran. Dalam hal ini, kemampuan guru dalam menggunakan model pembelajaran yang disesuaikan dengan kondisi lingkungan, karakteristik siswa, dan materi pembelajaran sangat diperlukan. Pemilihan dan penerapan metode pembelajaran yang tepat dan sesuai dengan kebutuhan pembelajaran pada setiap matakuliah merupakan salah satu faktor yang dapat mempengaruhi pencapaian hasil belajar mahasiswa, termasuk mata kuliah Teori Akuntansi.

Dalam upaya peningkatan hasil belajar mahasiswa, proses pembelajaran harus dilaksanakan dengan sebaik mungkin dengan menerapkan berbagai strategi pembelajaran yang memungkinkan keterlibatan aktif siswa.selama pembelajaran. Arends (2006) juga menjelaskan perlunya guru menerapkan dua strategi utama untuk memenuhi kebutuhan seluruh siswamenggunakan multiple models of 
instruction dan mendeferensiasikan pengajaran. Mengguakan multiple models berarti bahwa guru mengambil beberapa model dan repertoar mengajarnya dan memilih berbagi pendekatan yang berbeda secara tandem selama sebuah pelajaran atau sebuah unit pekerjaan sehingga siswa dapat belajar sesuai dengan potensinya.

Selain menjelaskan tentang penerapan dua strategi di atas, Arends (2006) mengemukakan bahwa baru-baru ini guru melihat kegunaan dari mengharuskan siswa untuk menciptakan presentasi multimedia sendiri, yang memasukkan teks, suara, video, dan grafik. Kebanyakan guru melaporkan bahwa tipe kegiatan belajar semacam ini dapat membantu siswa mencapai banyak tujuan belajar. Siswa sangat termotivasi dan mempelajari isi pelajaran dengan lebih menyeluruh karena diharuskan merancang sebuah presentasi dan mempresentasikannya kepada orang lain. Selain itu, siswa belajar bagaimana menggunakan teknologi dan software yang digunakan secara luas di dunia orang dewasa. Para guru membantu siswa dari semua usia untuk mengembangkan presentasi-presentasi multimedia. Hal ini juga sejalan dengan pendapat Smaldino (2006) dalam Suyanto (2012) yang menyatakan bahwa penggunaan teknologi dan media yang terintegrasi dengan strategi pembelajaran yang terencana dengan baik dapat meningkatkan belajar dan dapat mempengaruhi hasil belajar.

Salah satu program komputer yang sesuai untuk presentasi adalah program power point. Powerpoint dapat digunakan untuk mengembangkan metode pembelajaran. Menurut Muklas \& Thoyyib dalam Darmadi (2009), powerpoint merupakan program unggulan dalam membuat slide presentasi. Dengan media powerpoint ini, diharapkan dapat membantu mahasiswa mencapai tujuan belajar dan meningkatkan kualitas metode pembelajaran presentasi. Pemanfaatan powerpoint untuk mahasiswa akuntansi dihasilkan temuan, bahwa penggunaan powerpoint pada mahasiswa kelas akuntansi lebih baik digunakan pada matakuliah yang bersifat kualitatif (Khoury dan Mattar: 2012).

Berdasarkan paparan di atas, penelitian ini ingin menerapkan penggabungan metode presentasi diskusi dalam pembelajaran matakuliah Teori akuntansi. Penggabungan metode presentasi dan diskusi ini juga didukung oleh penelitian yang dilakukan Elison (2006) yang menyatakan bahwa metode presentasi diskusi memberikan pengaruh positif pada hasil belajar mahasiswa. Akan tetapi, hasil penelitian lain yang dilakukan Putra (2012) menemukan bahwa metode presentasi menghasilkan hasil belajar yang tidak berbeda dibandingkan metode STAD, dan dalam hal daya tarik mahasiswa terhadap metode pembelajaran, metode presentasi memiliki daya tarik lebih rendah dibandingkan dengan metode STAD.

Dari hasil temuan-temuan tersebut, terdapat perbedaaan hasil penelitian terkait dengan metode presentasi, sehingga diduga bahwa dalam meningkatkan proses pembelajaran dan hasil belajar yang lebih baik tidak hanya dipengaruhi oleh metode pembelajaran semata. Ada beberapa faktor yang mempengaruhi tinggi dan rendahnya prestasi belajar siswa, termasuk di dalamnya faktor intern dan faktor ekstern. Gaya belajar merupakan faktor intern yang terdapat dalam diri siswa yang dapat mendukung dan dapat juga menghambat prestasi belajar. Hal ini didukung oleh penelitian Richard Clark dalam Sujana (1995), hasil belajar siswa di sekolah bahwa $70 \%$ dipengaruhi oleh kemampuan siswa sendiri dan 30\% dipengaruhi oleh lingkungan.

\section{METODE}

Penelitian ini menggunakan jenis penelitian eksperimen yaitu penelitian yang melihat dan meneliti adanya akibat setelah subyek dikenal perlakuan pada variabel bebasnya. Dengan memperlihatkan variabel-variabel yang terkait dalam penelitian dan kondisi seperti di atas, maka rancangan penelitian yang digunakan adalah rancangan kuasi eksperimen. 


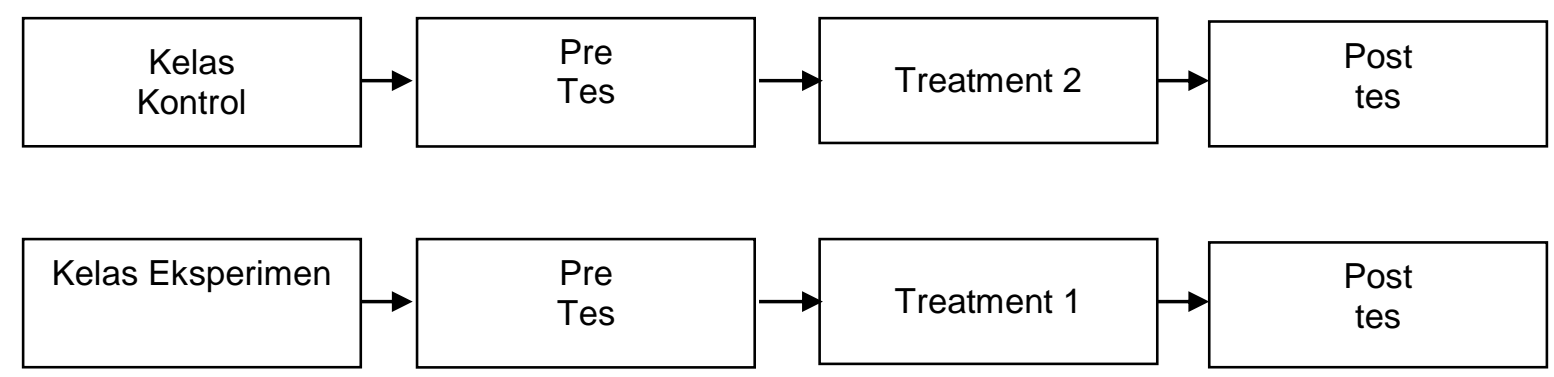

Gambar 1. Prosedur penelitian kuasi eksperimen

Berdasarkan desain penelitian di atas, peneliti menggunakan dua kelas penelitian, yaitu kelas ekperimen dan kelas kontrol. Kelas eksperimen melaksanakan metode presentasi diskusi dengan menggunakan media powerpoint, sedangkan kelas kontrol melaksanakan metode presentasi diskusi dengan menggunakan media makalah (handout). Langkah awal penelitian ini membuat kelas-kelas penelitian yang terdiri dari 2 kelas yaitu kelas eksperimen dan kelas kontrol. Kelas penelitian tersebut merupakan gabungan dari mahasiswa pada masing-masing kelas yang ada pada populasi diambil secara acak dan dibagi secara proporsional untuk dijadikan kelas eksperimen dan kelas kontrol. Setelah itu, langkah berikutnya adalah melakukan pretes pada kedua kelas tersebut untuk memastikan kedua kelas penelitian memiliki kemampuan awal yang sama (homogen) sebelum dilakukan perlakuan pada masing-masing kelas tersebut.

Tabel 1 Populasi dan sampel penelitian

\begin{tabular}{cccc}
\hline Populasi Semester VI & Jumlah Mahasiswa & Kelas Eksperimen & Kelas Kontrol \\
\hline Kelas 6A & 37 & 10 & 10 \\
Kelas 6B & 50 & 10 & 10 \\
Kelas 6C & 45 & 10 & 10 \\
Kelas 6D & 48 & 10 & 10 \\
Jumlah & 180 & 40 & 40 \\
\hline
\end{tabular}

\section{HASIL DAN PEMBAHASAN}

\section{Hasil Tes Kemampuan Awal (Pretes)} Kelas Eksperimen dan Kelas Kontrol

Data kemampuan awal mahasiswa

baik pada kelas eksperimen (media

Berdasarkan tabel 2 terlihat bahwa nilai kemampuan awal mahasiswa untuk kelompok kontrol dengan jumlah siswa 40 orang tersebar 20-45. Nilai tertinggi adalah 45 dan nilai terendah adalah 20 . Selanjutnya dari perhitungan diperoleh nilai rata-rata 30,25 dan standar deviasi powerpoint) dan kelas kontrol (media makalah) diambil dari hasil pretes. Adapun ringkasan statistik hasil belajar kelas eksperimen dan kelas kontrol dapat dilihat pada tabel 2

1,227. Nilai kemampuan awal untuk kelompok eksperimen dengan jumlah mahasisiswa 40 orang tersebar 20-45. Nilai tertinggi adalah 45 dan nilai terendah adalah 20. selanjutnya dari perhitungan diperoleh nilai rata-rata 30,38 dan standar deviasi 1,166. 
Tabel 2 Deskriptif Hasil Tes Kemampuan Awal Mahasiswa Kelas Eksperimen dan Kelas Kontrol

\begin{tabular}{lllll}
\hline Keterangan & \multicolumn{2}{l}{ Kelas Eksperimen } & Kelas Kontrol \\
\cline { 2 - 5 } Mean & Statistic & Std. Error & Statistic & Std. Error \\
Median & 30.38 & 1.166 & 30.25 & 1.227 \\
Variance & 30.00 & & 30.00 & \\
Std. Deviation & 54.343 & & 60.192 & \\
Minimum & 7.372 & 7.758 & \\
Maximum & 45 & 20 & \\
\hline
\end{tabular}

\section{Hasil Tes Kemampuan Akhir kelas Eksperimen dan kelas kontrol}

Data kemampuan akhir siswa baik pada kelas eksperimen (media powerpoint) dan kelas kontrol (media makalh) diambil dari hasil pos tes. Adapun ringkasan statistik hasil belajar kelas eksperimen dan kelas kontrol dapat dilihat pada tabel 3.

Berdasarkan tabel diatas terlihat bahwa nilai kemampuan awal mahasiswa untuk kelompok kontrol dengan jumlah siswa 40 orang tersebar 25-80. Nilai tertinggi adalah 80 dan nilai terendah adalah 25. Selanjutnya dari perhitungan diperoleh nilai rata-rata 54,50 dan standar deviasi 13,765.

Nilai kemampuan awal untuk kelompok eksperimen dengan jumlah mahasisiswa 40 orang tersebar 40-90. Nilai tertinggi adalah 90 dan nilai terendah adalah 40. Selanjutnya dari perhitungan diperoleh nilai rata-rata 62,25 dan standar deviasi 12,401 .

Tabel 3 Deskriptif Hasil Belajar Kemampuan Akhir Mahasiswa Kelas Eksperimen dan Kelas Kontrol

\begin{tabular}{lllll}
\hline Keterangan & \multicolumn{2}{l}{ Kelas Eksperimen } & \multicolumn{2}{l}{ Kelas Kontrol } \\
\cline { 2 - 5 } & Statistic & Std. Error & Statistic & Std. Error \\
Mean & 62.25 & 1.961 & 54.50 & 2.177 \\
Median & 60.00 & & 55.00 & \\
Variance & 153.782 & & 189.487 & \\
Std. & 12.401 & & 13.765 & \\
Deviation & & & \\
Minimum & 40 & 25 & \\
Maximum & 90 & 80 & \\
\hline
\end{tabular}

Pengaruh Metode Presentasi Diskusi Dengan Media Powerpoint Terhadap Hasil Belajar

Hasil pengujian disajikan pada tabel 4. Dari tabel 4, hasil uji t menunjukkan bahwa nilai Sig $(0,010)<\alpha(0,05)$ dan $t_{\text {hitung }}=2,646>t_{\text {tabel }}=1,991$. Sehingga $H_{0}$ yang menyatakan "tidak ada perbedaan pengaruh yang signifikan media presentasi diskusi terhadap hasil belajar mahasiswa pada matakuliah Teori
Akuntansi ditolak yang berarti terdapat perbedaan hasil belajar antara kedua kelas penelitian yaitu kelas eksperimen yang menggunakan media powerpoint dan kelas kontrol yang menggunakan makalah.. Dengan demikian dapat disimpulkan bahwa media presentasi diskusi dengan menggunakan media powerpoint mempunyai pengaruh yang signifikan terhadap hasil belajar siswa pada matakuliah teori Akuntansi 
Tabel 4 independent sample t test

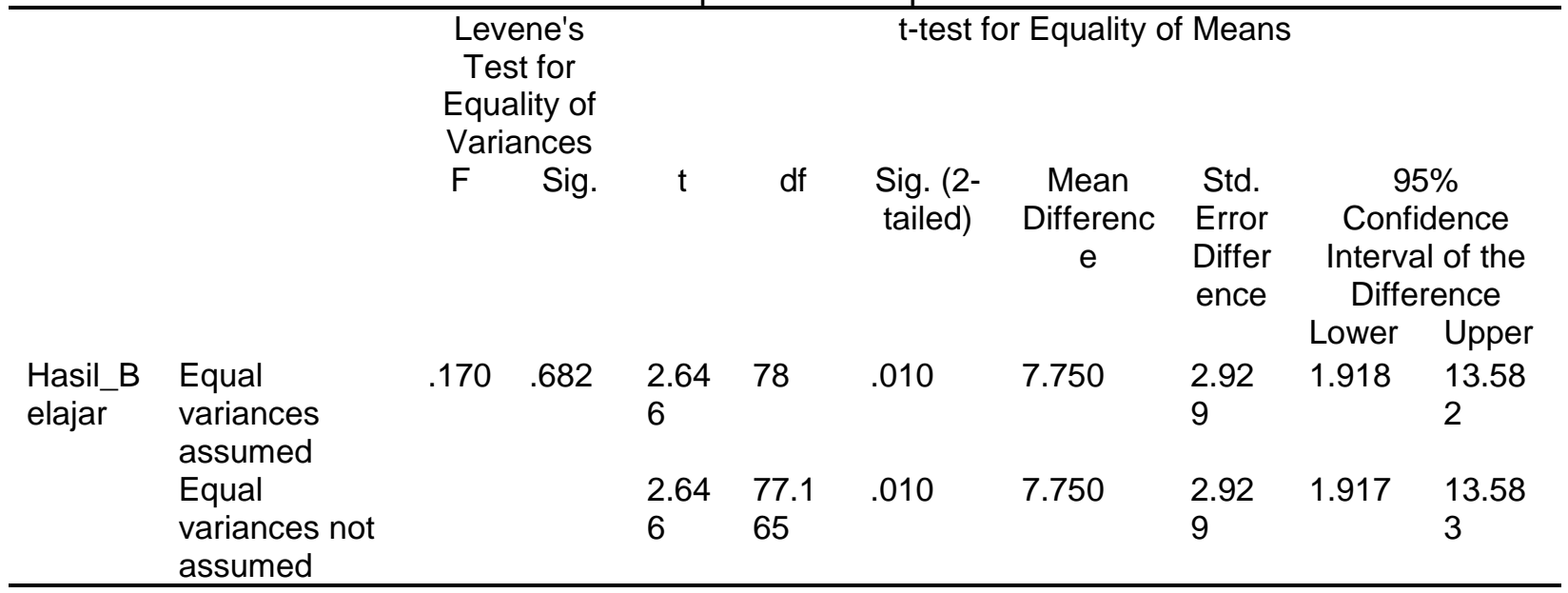

Pengaruh Metode Presentasi Diskusi Dengan Media Powerpoint Terhadap Hasil Belajar

Hasil penelitian ini menunjukkan bahwa aspek pemanfaatan media pembelajaran juga merupakan aspek penting yang perlu diperhatikan para pendidik dalam mengembangkan dan menerapkan metode pembelajaran yang akan dilakukan. Dengan adanya pemanfaatan media yang tepat dalam pembelajaran dapat membantu mahasiswa dalam menyerap informasi yang diterima, sehingga akan berlanjut pada pencapaian hasil belajar yang diharapkan. Hal ini sesuai dengan pendapat Smaldino (2006) dalam Suyanto (2012) yang menyatakan bahwa penggunaan teknologi dan media yang terintegrasi dengan strategi pembelajaran yang terencana dengan baik dapat meningkatkan belajar dan dapat mempengaruhi hasil belajar.

Selain itu, hasil penelitian ini juga sebagai tindak lanjut dan sejalan dengan temuan yang dilakukan oleh El Khoury dan M. Mattar (2012) tentang penggunaan powerpoint dalam kelas akuntansi mengungkapkan bahwa dalam kelas akuntansi untuk materi akuntansi yang bersifat kualitatif $80,1 \%$ mahasiswa lebih menyukai pengajaran dengan penggunaan media powerpoint, sedangkan 19,9\% mahasiswa menyukai metode pengajaran tradisonal.

Dengan demikian, dapat disimpulkan bahwa aspek pemanfaatan media pembelajaran merupakan aspek penting yang harus diperhatikan dalam mengembangkan dan menerapkan metode pembelajaran. Hasil penelitian ini juga sejalan dan sebagai tidak lanjut dari temuan penelitian sebelumnya yang dilakukan oleh El Khoury dan M. Mattar (2012). Jadi penelitian ini membuktikan bahwa pemanfaatan media powerpoint dalam metode presentasi diskusi dapat memberikan pengaruh terhadap hasil belajar.

\section{SIMPULAN DAN SARAN}

Berdasarkan hasil penelitian yang telah dilaksanakan diperoleh kesimpulan yaitu terdapat pengaruh metode presentasi diskusi dengan media powerpoint terhadap hasil belajar mata kuliah teori akuntansi pada mahasiswa Program Studi Pendidikan Ekonomi Akuntansi di FKIP Universitas Islam Riau. Implikasi hasil penelitian ini secara teoritis memperkuat penjelasan dan pendapat Arends (2006), bahwa perlunya guru menerapkan dua strategi utama untuk memenuhi kebutuhan seluruh siswa-menggunakan multiple models of instruction dan mendeferensiasikan pengajaran. Menggunakan multiple models berarti bahwa guru mengambil beberapa model dan repertoar mengajarnya dan memilih berbagi pendekatan yang berbeda secara tandem selama sebuah pelajaran atau sebuah unit pekerjaan sehingga siswa dapat belajar sesuai dengan potensinya. Hasil penelitian ini juga memperkuat penjelasan dan pendapat Smaldino (2006) dalam Suyanto (2012) yang menyatakan bahwa penggunaan teknologi dan media yang 
terintegrasi dengan strategi pembelajaran yang terencana dengan baik dapat meningkatkan belajar dan dapat mempengaruhi hasil belajar.

Hasil penelitian ini juga memberikan masukan pada dosen untuk melihat dan mengenali keanekaragaman karakteristik mahasiswa. Keanekaragaman tersebut juga memberikan masukan bagi dosen dalam menerapkan berbagai metode mengajar, hal ini diperlukan agar kebutuhan akan belajar dari keanekaragaman karakteristik mahasiswa dapat terpenuhi. Selain menerapkan metode mengajar yang beragam, penggunaan media pembelajaran yang digunakan juga perlu variasi pada saat proses perkuliahan, serta harus terintegrasi dan terencana dengan baik dengan metode pembelajaran yang diterapkan. Hal ini sebagai salah satu upaya dalam proses pembelajaran sehingga dapat memberikan kontribusi positif dalam upaya peningkatan hasil belajar mahasiswa.

\section{DAFTAR RUJUKAN}

AECT, Task Force. 1977. The Definition of educational Technology. Jakarta: CV. Rajawali.

Alley, M., Schreiber, M., Ramsdell, K., \& Muffo, J. (2006). How the design of headlines in presentation slides affects audience retention. Technical Communication,53(2), 233.

Bobbi de Porter \& Mike Hernacki. 1992. Quantum Learning-Membiasakan Belajar Nyaman dan Menyenangkan. Terjemahan Alwiyah Abdurrahman. 2006. Bandung: Penerbit Kaifa.

Brown, J.W., Lewis, R. B., Harcleroad, F.F. 19983. AV Istruction Technology, Media, and Methods. New York: McGraw-Hill, Inc.

Darmadi. 2009. Pengaruh Pemanfaatan Powerpoint Dalam Pembelajaran Terhadap Prestasi Belajar Matematika Tingkat Sekolah Dasar Ditinjau Dari Gaya Belajar Siswa. Jurnal Pendidikan IKIP PGRI Madiun, (Online), 15 (1): 99-112, (http://isjd.pdii.lipi.go.id/index.php/
Search.html?act=tampil\&id=69215 \&idc=32), diakses 15 Desember 2012.

Degeng, I. N. S. 1989. Desain Pembelajaran: Teori dan Praktek. Malang: Penyelenggaraan Pendidikan Pascasarjana Proyek Peningkatan Perguruan Tinggi IKIP Malang.

DePorter, Bobbi, dkk. 2002. Quantum Teaching: Mempraktekkan Quantum Learning Di RuangRuang Kelas. Bandung : Kaifa

Dimyati dan Mujiono. 1994. Belajar dan

Pembelajaran. Jakarta:

Departemen Pendidikan dan

Kebudayaan.

Elison. 2006. Pengaruh Tutorial Presentasi Diskusi Terhadap Hasil Belajar Mata Kuliah Pendidikan IPA di SD Pada Unit Program Belajar Jarak Jauh Universitas Terbuka (UPBJJ-UT) Palangkaraya. Tesis Tidak Diterbitkan. Malang: Universitas Negeri Malang Program Pascasarjana.

Gaiger. 1992. Learning Style of Student and Instructor: an Analysis of Course Performance and Satisfaction.The Accounting Education Journal.

Ibrahim, dkk. 1982. Pengantar Teknologi Pendidikan. Malang: Laboratorium Jurusan KTP IKIP Malang

Irwanto. (1997). Psikologi Umum. Jakarta : PT. Gramedia Pustaka Utama.

Khoury \& Mattar. 2012. PowerPoint in Accounting Classrooms: Constructive or Destructive?. International Journal of Business and Social Science, (Online), 3 (10): 240-259, (http://www.google.com/url?sa=t\&r $c t=j \& q=\& e s r c=s \&$ source $=$ web \& $c d=$ $1 \& \mathrm{cad}=\mathrm{rja} \& v e d=0 \mathrm{CDEQFjAA} \& u r l=$ http\%3A\%2F\%2Fwww.ijbssnet.co m\%2Fjournals\%2FVol_3_No_10_ Special_Issue_May_2012\%2F $25 . p$ df\&ei=scQAUfijE4j8rAfU14C4Ag\&u $\mathrm{sg}=$ AFQjCNE6_PKqbrExFjf4yRJU pLCaEyddSw\&bvm=bv.41524429, d.bmk), (www.ijbssnet.com/journals/Vol_3_ 
No_10_Special.../25.pdf), diakses 17 Desember 2012.

Kolb, David A. 1984. Experiential Learning. New Jersey : Prentice Hall, Inc. Englewood Cliffs.

Latuheru, J.D. 1988. Media Pembelajaran. Jakarta: Depdikbud Dikti PPLPTK.

Mayferani, Frida. 2010. Peningkatan Kreatifitas Dan Hasil Belajar Matematika Tentang Lingkaran Melalui Pemanfaatan Media Powerpoint Bagi Siswa Kelas VIII Smp Negeri 2 Bangsri Semester II Tahun 2009/2010. Adi Cendikia : Jurnal Pendidik dan Tenaga Kependidikan, (Online), 3 (3): 1924,

(http://isjd.pdii.lipi.go.id/index.php/ Search.html?act=tampil\&id=57950 \&idc=32), diakses 15 Desember 2012.

Meutia, Nila. 2008. Pengaruh strategi pembelajaran dan gaya belajar terhadap hasil belajar sejarah. Jurnal Teknologi Pendidikan, (Online), $10 \quad$ (2): 87-98, (http://isjd.pdii.lipi.go.id/index.php/ Search.html?act=tampil\&id=59854 \&idc $=32$,

http://isjd.pdii.lipi.go.id/admin/jurnal /102088798.pdf,

http://www.google.com/url?sa=t\&rc $\mathrm{t}=\mathrm{j} \& \mathrm{q}=$ \&esrc $=\mathrm{s} \&$ source $=$ web $\& \mathrm{~cd}=1$ $\& \mathrm{cad}=\mathrm{rja} \& \mathrm{ved}=0 \mathrm{CC} 4 \mathrm{QFjAA} \& u \mathrm{ul}=\mathrm{ht}$ tp\%3A\%2F\%2Fisjd.pdii.lipi.go.id\% 2Fadmin\%2Fjurnal\%2F102088798 .pdf\&ei=X88AUZfHOMT_rAeo9YG ICQ\&usg=AFQjCNELNNfe35fsLX KDou2sf3K5gTG6HQ\&bvm=bv.41 524429,d.bmk), diakses 18 desember 2012.

Mukhlas \& Thoyyib. 2005. Presentasi Interaktif Cantik dengan Microsoft PowerPoint 2003. Surabaya: Indah Surabaya

Nurkancana, Wayan. 1986. Evaluasi Pendidikan. Surabaya: Usaha Nasional

Phibin, M., Meier, E., Huffman, S., and Bouverse, P. 1995, April. A Survey of gender and Learning styles. Sex Roles, 32, 484-494.

Putra, Miftah Fariz Prima. 2012. Pengaruh Metode Pembelajaran (STAD vs Presentasi) dan Lokus Kendali
Terhadap Hasil Belajar (Keefektifan Dan Daya Tarik Pembelajaran) Mahasiswa Pada Matakuliah Metodologi Penelitian di Jurusan Pendidikan Olah Raga Fakultas IImu Keolahragaan Universitas Negeri Surabaya. Tesis Tidak Diterbitkan. Malang: Universitas Negeri Malang Program Pascassarjana.

Reisman, F. \& Payne, B. 1987. Elementary education. Columbus, Ohio: Merril Publishing Company.

Sadiman,A. 2002. Media Pendidikan Pengertian, Pengembangan dan Pemanfaatan. Jakarta: PT. Raja Grafindo.

Sawitri \& Pujiningsih. 2009. Pengaruh faktor preferensi gaya belajar terhadap prestasi belajar mahasiswa akuntansi. Jurnal Ekonomi Bisnis, (Online), 14 (3): 224-231,

(http://isjd.pdii.lipi.go.id/index.php/ Search.html ?act=tampil\&id=82129 \&idc $=32$, http://www.google.com/url?sa=t\&rc $\mathrm{t}=\mathrm{j} \& \mathrm{q}=\&$ esrc $=\mathrm{s} \&$ source $=$ web\& $\mathrm{cd}=1$ $\& \mathrm{cad}=\mathrm{rja} \& \mathrm{ved}=0 \mathrm{CDEQFjAA} \& u \mathrm{rl}=\mathrm{h}$ ttp\%3A\%2F\%2Ffe.um.ac.id\%2Fwp

content\%2Fuploads\%2F2010\%2F 01\%2Fsawitri_pujiningsih_6.pdf\&ei $=\mathrm{L} 8 \mathrm{kAUeOYJcOGrAfMp} 4 \mathrm{HQCg} \& \mathrm{u}$ $\mathrm{sg}=A F Q j C N F E F O 8 C g q 0 T r j z T j 7 \mathrm{Jxj}$ BhgpxaLtw\&bvm=bv.41524429, d.b mk), diakses 18 desember 2012.

Setyosari, Punaji. 1990. Pengajaran Modul. Malang : Proyek Operasi dan Perawatan Fasilitas IKIP Malang

Slameto. 2003. Belajar Dan Faktor-Faktor Yang Mempengaruhi . Jakarta : Rineka Cipta.

Slameto. 2003. Belajar dan Faktor-Faktor yang Mempengaruhinya. Jakarta ; Rineka Cipta

Slavin, R. E. 2000. Educational psychology: Theory and practice. Sixt Edition. Boston: Allyn and Bacon.

Smaldino, S.E., Lowther, D.L., \& Rusell, J.D.. $\quad 2008$. Introductional Technology \& Media for Learning. Teknologi Pembelajaran da Media 
untuk Belajar. Terjemahan oleh Arif Rahman. 2011. Jakarta: Kencana.

Sugiyono. 2004. Metodelogi Penelitian Bisnis. Bandung. CV Alva Beta.

Surahman, Endang. 2010. Upaya Peningkatan Hasil Belajar Siswa Dengan Menggunakan Media Powerpoint Pada Relativitas: Penelitian Tindakan Kelas Pada Siswa Kelas XII.la.1 SMA Negeri 1 Tasikmalaya. Paedagogi : Jurnal Pendidikan dan IImu Pengetahuan, (Online), 6 (1): 13-34, (http://isjd.pdii.lipi.go.id/index.php/ Search.html?act=tampil\&id=96380 \&idc=32), diakses 15 Desember 2012.
Suyanto, Moh. Edi. Pengaruh Penggunaan Variasi Media dalam PembelajaranInkuiri dan Gaya Belajar terhadap Hasil Belajar Fisika Kelas X SMA. Disertasi Tidak Diterbitkan. Malang: Universitas Negeri Malang Program Pascassarjana.

Tobias, Cynthia Ulrich. 1996. Cara Mereka Belajar. Alih bahasa: Yohanan Kwee Han Tiong. Jakarta: Harvest Publication House.

W. James Popham dan Eva L. Baker.2005. Teknik Mengajar Secara Sistematis (Terj. Amirul Hadi, dkk). Jakarta: Rineka Cipta.

Winkel, W. S. 1991. Psikologi Pengajaran. Jakarta: PT Grasindo. 